\title{
Affinity of Mindscape and Landscape in Tao Qian and Emerson*
}

\author{
King-Kok Cheung \\ University of California, Los Angeles, USA
}

\begin{abstract}
This paper compares the reclusive ideal extolled by Chinese poet Tao Qian (T'aoCh'ien or Tao Yuanming) and the solitude that Ralph Waldo Emerson regards as a prerequisite to self-trust. Tao Qian and Emerson are the fathers of Chinese and American pastorals respectively. Both the Chinese poet and the New England sage disparage the social, economical, and political pressures that curtail individual spirit, as well as material aggrandizement and social conformity, deem nature to be at once salubrious and edifying, and discern correspondences between ecological and moral well-being. Their differences are no less pronounced. Tao Qian, who considers the countryside to be essential to solitude, is content to lead a self-effacing pastoral existence. Emerson, who sees nature as ancillary to the divine spark within each human being, avers that the enlightened soul can find solitude anywhere. While Tao Qian believes that he can only be true to his high-minded nature by literally removing himself from the world of affairs, Emerson never shirks his responsibility as a public intellectual and always weighs in with a piece of his mind concerning pressing social and political issues.
\end{abstract}

Keywords: Emerson, Tao Qian, solitude, pastoral, Taoism, Transcendentalism

\section{Introduction}

Although Tao Qian 陶潜 (also known as Tao Yuanming 陶渊明 and Sire of the Five Willows 五柳先 生, 365-427 CE) and Ralph Waldo Emerson (1803-1882) hail from different epochs and continents, the two arguably have inaugurated Chinese and American pastorals, respectively. Tao Qian, the preeminent "recluse" poet of the Six Dynasties period, spearheaded the "Return Home to the Farm" tradition, while Emerson (along with his disciple Henry David Thoreau and Walt Whitman) ushered in American Transcendentalism. Their considerable impact went beyond national borders into each other's country. Tao Qian has inspired not only Tang and Song poets such as Li Po 李白, Tu Fu 杜甫, and Su Shi 苏轼, but also American Beat writers of the 1950s and 1960s. ${ }^{1}$ Emerson is venerated not only by American and European luminaries such as Thoreau, Whitman, Thomas Carlyle, and Friedrich Nietzsche, but also by diasporic Chinese writers such as Gao Xingjian and Ha Jin. Most remarkable are the multiple convergences of the reclusive ideal of Tao Qian and the

\footnotetext{
* Earlier versions of this paper were presented at the International Association for Comparative Study of China and the West, Peking University, July 14-16, 2013 and Ninth Annual International Conference on Chinese and American Comparative Literature, Nanjing University, July 18-20, 2014. An excerpt has appeared in Comparative Studies of China and the West 1 (2013: 62-74) and a Chinese version, entitled “心境互照: 陶潜的隐居理想与爱默生的超验主义愿望” (Li Hanping (李汉平), Trans.) will appear in《中西文化比较与翻译研究论集》[Chinese and Western Literature and Translation Studies] (2015), Gu Zhengkun 幸正坤 (Ed.). Beijing: Higher Education Press (高等教育出版社)). I thank my colleague Michael Cohen for his most helpful comments; Hannah Nahm and Robert Kyriakos Smith for their scrupulous research assistance.

King-Kok Cheung, Ph.D., professor, Department of English, University of California, Los Angeles (UCLA).

1 Jack Kerouac's “Running Through (Chinese Poem Song)" (1961), for example, contains the lines "Nobody has respect/for the self centered/Irresponsible wine invalid./Everybody wants to be strapped/in a hopeless space suit where they can't move./I urge you, China/go back to Li Po and Tao Yuan Ming”.
} 
transcendentalist worldview of Emerson: Both writers take for granted the contiguity of ecological and moral landscape, of nature and existential solitude; both prefer independent living to social conformity, wealth, or fame. Despite their parallel conviction in the linkage between topos and ethos, between nature and intuition, and between landscape and mindscape, they differ markedly in their conceptions of "self" and "nature" and in their visions of the relationship between self, nature, and society. Tao Qian feels the need to cultivate virtue in a Spartan setting; for him the self should seek to live in unison with nature, which could be found only in the countryside. Emerson holds that the mind can prevail over any environment; for him both human and nature (whose meaning keeps shifting in his oeuvre) partake of divine intelligence, and an open mind could access natural solitude anywhere. The two also respond in disparate fashions to public service and governmental interference. Tao Qian resigns from official posts and "returns" to the countryside, which he relishes as a "natural" abode. Emerson, though also averse to social organizations, including organized charity and reform societies, never ceases to be a public intellectual who speaks out vehemently against unjust policies.

Through an analysis of selected works by Tao Qian and Emerson, this paper marks their common religious and literary predilections, their revelry in nature and solitude, as well as their divergent construals of selfhood and responses to society. The first section of this essay shows the Taoist inflection in Tao Qian's reclusiveness and Emersonian Transcendentalism, in their reverence for nature and antipathy to social and political demands. The second examines the confluence of ecological and ontological climates in their works. The third contrasts their views concerning the relationship between self and nature. The fourth sets Tao Qian's quiescence against Emerson's activism. The last illustrates how their spiritual and stylistic orientation comports with their pastoral ideal.

\section{Taoist Impact on the Reclusive and Transcendentalist Appreciation of Nature}

Tao Qian and Emerson are of like mind that human beings should be nature-centered rather than society-centered. Their mutual conviction in the human spirit's intimate relationship with nature is consonant with Taoism. Tao Qian lived during a period marked by warfare and instability in the years between the collapse of the Han dynasty (220 CE) and the reunification of northern and southern dynasties by the Sui Dynasty (589 CE). He embraces a simple life close to nature and decries the pernicious effects of politics and commerce. Quitting official life to farm in the countryside, he exemplifies the Taoist virtues of humility, gentleness, resignation, quiescence, and contentment. He says of himself in "The Life of the Sire of Five Willows”《五柳先生传》 (hereafter “Life”), his self-portrait: “Living quietly in solitude and spare of speech, he covets not rank nor wealth [闲静少言，不慕荣利]” (Sun 72-73). His Taoist bent is further evident in lines such as “The Tao has been lost... And people everywhere are misers of their feelings [道丧向千载，人人惜其情]”; “The life of man is like a shadow-play/Which must in the end return to nothingness [虽留身后名/一生亦枯槁]” (Sun 72); and in his persistent association of nature with individualist freedom (as opposed to Confucian emphasis on duty and hierarchy). ${ }^{2}$ As recorded in his autobiographical "Five Poems on Returning to Dwell in the Country” 《归园田居五首》, Tao Qian considers the life of affairs in the city to be a “net” or a “cage”, and the countryside to be his natural habitat: "Inadvertently I fell into the Dusty Net... Too long I was held within the barred cage./Now I am able to return again to Nature [误落尘网中……文在森笼里, 复得返自然]” (Acker

\footnotetext{
2 T'aoCh'ien, “Six Poems Written While Drunk” and “Five Poems on Returning to Dwell in the Country”, in William Acker, trans., T'ao the Hermit 65, 56; Chinese original in Xu Wei 徐巍 (Ed.), 《陶渊明诗选》 65, 28. All English and Chinese citations of Tao Qian are to Acker's and Xu's texts unless otherwise stated.
} 
52-53; Xu 24-25). Urban living, to borrow from Macbeth, is “cabined, cribbed, confined”.

Taoist philosophy also seems to resonate with Emerson. Whether he has actually read The Book of Tao and Teh (c. 4th century B.C.) is open to speculation, for most scholarly discussions of his indebtedness to Oriental thought are confined to Persian, Hindu, and Hebrew influences, though his familiarity with Confucian classics has been documented extensively by Frederic Ives Carpenter (1930) and Arthur Christy (1932) (see also Dimock, 2006; Gura, 2008; Obeidat, 1988; Packer, 2007; Richardson, 1996). According to Lyman V. Cady (1961), “Thoreau's acquaintance with Oriental texts began with his residence in Emerson's home in 1841" (20), and among the Oriental books in Emerson's private collection were Joshua Marshman's The Works of Confucius (1809) and David Collie's The Chinese Classical Work, Commonly Called the Four Books (1828), the latter being also Confucian classics. ${ }^{3}$ Emerson has obviously read French translations of Chinese texts as well. The name of the French Sinologist Jean Pierre Abel Rèmusat (1788-1832), Christy indicates, "was often on the tongues of the Concordians"; Emerson even marked in his journal that Rèmusat's L'Invariable Milieu (1817) begins with "promising definitions” of nature (Christy 45, 317). Although L'Invariable Milieu is also a translation of The Four Books, Rèmusat's "Extrait d'un memoire sur Lao Tseu”, which "dealt with parallels of Taoism, Plato, and Pythagoras” appeared in the Journal Asiatique of 1823 (Christy 49). Emerson, given his exhaustive reading and his familiarity with Rèmusat's other works, might have come across this article, pace Carpenter's assertion to the contrary: "Lao-tse [Emerson] had never read" (235). David T. Y. Chen, in “Thoreau and Taoism” (1972), reports that another French translation of Taoist texts, G. Pauthier’s Memoire sur l'Origin et la Propagation de la Doctrien du Tao, published in 1831 by Libraire Orientale, was also available to the Concordians- a translation Chen strongly suspects Thoreau to have read (409). If so, Thoreau's mentor is unlikely to be oblivious of its content.

Because its author is not a Sinologist, the present paper refrains from claiming any definitive imprint of Lao Zi on Emerson. Yet one of the most elusive concepts in Transcendentalism, about an all-encompassing spirit that is the source of all wisdom and intuition, is highly reminiscent of The Book of Tao and Teh: "Tao is invisibly empty,/But its use is extremely plentiful. It is profound like the originator of all things.... I do not know where it comes from/It seems to have appeared before the existence of God [道冲，而用之有弗盈也。渊 呵! 似万物之宗……吾不知其谁之子，象帝之先]” (Gu 11). Compare this with Emerson’s formulation of the primal Intuition:

Who is the Trustee [of self-trust]? The inquiry leads us to that source, at once the essence of genius, of virtue, and of life, which we call Spontaneity or Instinct. We denote this primary wisdom as Intuition... In that deep force, the last fact behind which analysis cannot go, all things find their common origin... We lie in the lap of immense intelligence, which makes us receivers of its truth and organs of its activity... If we ask whence this comes, if we seek to pry into the soul that causes, all philosophy is at fault. ${ }^{4}$

Emerson's premise about a pervasive spirit with no beginning and no end, that is at one with all things, has an insistent Taoist ring. Gu Zhengkun, the translator of The Book of Tao and Teh, observes: "Taoism is systematically constructed with four integral parts: (1) Tao as the ontological being, (2) Tao as the dialectic law,

\footnotetext{
${ }^{3}$ Cady also makes a convincing case from textual evidence that Thoreau is also familiar with G. Pauthier's Les Livres sacrés de L'Orient (1841), a French translation of The Four Books.

${ }^{4}$ Ralph Waldo Emerson, "Self-Reliance”, in Carl Bode and Malcolm Cowley (Eds.), The Portable Emerson (pp. 149-150); all citations from Emerson are to The Portable Emerson unless otherwise stated. Emerson is also very much influenced by British poets (e.g., Wordsworth and Coleridge) whose works reflect Eastern philosophical currents.
} 
(3) Tao as the epistemological tool, and (4) Tao as a practical guide to worldly affairs” (30). Emerson's Intuition similarly has an ontological, dialectical, epistemological, and practical dimensions.

Also highly redolent of "Tao" is Emerson’s bedeviling exposition of "nature”, which ranges from a common understanding of the word as designating outdoor terrains such as woods, fields, and mountains to much more abstract and elusive entities approximating "over-soul”, "divinity”, and "spirit":

The lover of nature is he whose inward and outward senses are still truly adjusted to each other... In the presence of nature a wild delight runs through the man... Crossing a bare common... I have enjoyed a perfect exhilaration... In the woods, too, a man casts off his years... In the woods its perpetual youth... In the woods, we return to reason and faith. Standing on the bare ground, — my head bathed by the blithe air and uplifted into infinite space, —all mean egotism vanishes. I become a transparent eyeball; I am nothing; I see all; the currents of the Universal Being circulate through me; I am part or parcel of God... I am the lover of uncontained and immortal beauty. (Nature, 10-11)

Like Tao Qian, Emerson sings the praises of nature as a conduit to "perfect exhilaration"; thrice he uses the phrase "in the woods" to underscore its rejuvenating power, wherein one can cast off years, enjoy perennial youth, and recover reason and faith. Like Lao Zi, Emerson wraps his head around the ecstasy of being at one with nature. There is no original sin that separates human beings from God, but any mortal can partake of the beneficent Universal Being, much in the way that Tao is everywhere accessible.

Lao Zi's notions about the law of nature and about the paradox of "less is more" similarly surface in Tao Qian's and Emerson's writing. Both the Chinese poet and the American doyen favor a simple life of wandering in the woods, removed from the din of the city and unencumbered by wealth, power, or official duty. In "Peach Blossom Spring”《桃花源记》, Tao Qian's utopian fable, a fisherman who follows the course of a brook through a grotto finds a grove aflame with blossoming peach trees (Birch 167-168; Xu 136-137). By leaving his boat and walking through a small pass, he comes upon a village founded dynasties ago by refugees from wars, draft, taxation, economic rivalry, and political persecution. No potentate controls the populace in this egalitarian community, where villagers make their living by farming and raising cattle. After the fisherman returns to his prefecture he informs the prefect of the unique village, but when officers are dispatched to go back with the fisherman, he is unable to locate the wonderland again. Peach Blossom Spring, Tao Qian implies, exists only in the imagination. In the fable, the ruling class is responsible for the ills of society; magistrates often reek of toadyism, rapaciousness, and oppression. Both officialdom and affluence (which tend to go in tandem) are deemed corrupting, unworthy of a poet's pursuit and detrimental to artistic integrity. Tao Qian himself resigned from the Jin court to become a farmer and lived in the countryside for 22 years before he died at 63; he is known for his acerbic refusal to "grovel to petty provincial functionaries for his livelihood [我岂能为五斗米, 折腰乡里小儿]” (literally, “How can I bend my waist for five bushels of rice?”) (Xu 2; the author’s translation).

Although Emerson never worked as a bureaucrat, he gave up his secure post as Unitarian minister in 1832 when he was scarcely 30, "without any assurance that he [would] ever be employed again” (Bode ix). After touring Europe, he retired to the Old Manse in Concord in 1834 to live with his step-grandfather. Like Tao Qian, he associates official life with spineless conformity and looks askance at social mores, religious creeds, and national laws: "the wise know that foolish legislation is a rope of sand, which perishes in the twisting; that the State must follow, and not lead the character and progress of the citizen" ("Politics," 254). In other words, individuals must abide by their innate promptings even if these run afoul of official edicts.

Emerson's ruminations about solitude and nature, like Tao Qian's reclusive ponderings, are grounded in 
"the presumed opposition between the realm of the collective, the organized, and the worldly on the one hand, and the personal, the spontaneous, and the inward on the other" (Marx 44). Tao Qian senses a palpable rapport between self and nature; Emerson finds "something more dear and connate [in the wilderness] than in streets and villages” (11). A starry sky can induct someone into solitary selfhood:

To go into solitude, a man needs to retire as much from his chamber as from society. I am not solitary whilst I read and write, though nobody is with me. If a man would be alone, let him look at the stars. The rays that come from those heavenly worlds, will separate him and what he touches.... The stars awaken a certain reverence, because though always present, they are inaccessible. (9)

This passage suggests that solitude is a sublime experience accessible to the human faculty in nature's presence. Just as Tao Qian credits his bucolic surroundings with insulating him from the "vulgar tone" of the city and allowing him to regain his intrinsic self (“Five Poems," 52), so Emerson lauds the restorative power of the natural landscape:

To the body and mind which have been cramped by noxious work or company, nature is medicinal and restores their tone. The tradesman, the attorney comes out of the din and craft of the street, and sees the sky and the woods, and is a man again. (14)

Both men concur that humankind can get in touch with the sacred core of their beings through firsthand communion with nature.

\section{Correspondence Between Topos and Ethos}

Nature is more than healing and restorative. Tao Qian and Emerson look to it for existential, intellectual, and moral edification, as well as for poetic and philosophical inspiration. Both, for example, find in plants the model of carefree and glorious living. Tao Qian muses in “Spending the Ninth Day in Solitude” 《九日闲居》:

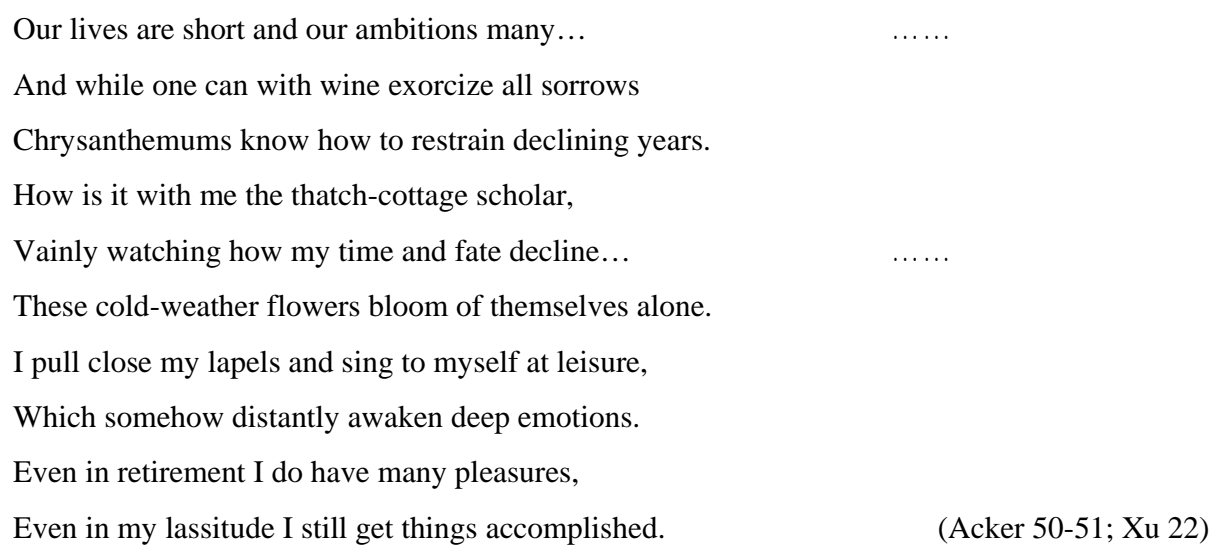

The poet learns from chrysanthemums to live with gusto even in the face of adversity or death, instead of bemoaning missed opportunities or grieving about twilight years. By living life to the brim each morn, implicitly in nature's lap, one can catch intimations, if not of immortality then at least, of vibrant mortality. He sketches a comparable scenario in "Life":

As there are five willows beside his abode, he has called himself by such a title.... His short coats of coarse fabric are patched and knotted, his reed cereal case and gourd shell for liquid food are often empty: but he takes such at his ease... He quaffs at his beaker and chants his poems to find happiness in his sublimating will. Isn't he a free, blissful subject of 
our legendary kings at the dawn of the world, the One of Care-free Rule and the One of Heavenly Grace? [宅边有五柳树， 因以为号焉……短褐穿结, 箪漂屡空, 晏如也……衔鵤赋诗, 以乐其志, 无怀氏之民领? 葛天氏之民拎? ] (Sun 72-75)

The "five willows" refer explicitly to the shrubs outside his house, but the soubriquet nicely befits a sire who enjoys a blithe if slender existence. Despite his meager means, he likens his persona to the happy subjects of legendary kings in prehistorical times (rulers who exercised a Taoist form of libertarianism), exulting at being a free, blissful soul heedless of material abundance and worldly renown.

Nature also vouchsafes Emerson virtual majesty: "Give me health and a day, and I will make the pomp of emperors ridiculous. The dawn is my Assyria, the sun-set and moon-rise my Paphos” (14-15). Regal pomp and circumstance dwarf beside natural bounty, which teaches by luscious examples how to live with aplomb in the present:

Man is timid and apologetic; he dares not say "I think," "I am,” but quotes some saint or sage. He is ashamed before the blade of grass or the blowing rose. These roses under my window make no reference to former roses or to better ones; they are for what they are; they exist with God today.... But man postpones or remembers; he does not live in the present, but with reverted eye laments the past, or, heedless of the riches that surround him, stands on tiptoe to foresee the future. He cannot be happy and strong until he too lives with nature in the present, above time. ("Self-Reliance," 151)

The blade of grass and the blowing rose call forth the biblical "lilies of the field" that neither toil nor spin (Matthew 6:28), offering the New England seer a lesson congruent with the one set by chrysanthemums for the Chinese poet. Humankind too can bask in the moment, instead of measuring themselves against predecessors, submitting themselves to ancient authority, regretting the past, or fretting about the future. For both Tao Qian and Emerson, the riches that nature affords outweigh any worldly gratifications or recognitions. It is telling, however, that while Emerson compares these riches with royal splendor (as a close analogue that still falls short), Tao Qian equates them with the luxury of being a subject under benign rule. This minor difference perhaps indicates that Tao Qian, much as he has absorbed Taoist thinking, still adheres to the Confucian ideal of righteous governance, while Emerson seems more than glad to dispense with any form of authority.

Nature, which both Tao Qian and Emerson regard as the perfect classroom, is also conducive to their common goal of self-cultivation. Far from associating it with untrammeled wilderness or barbarity, the two thinkers are genteel countryside dwellers who cherish a life of farming and study. Tao Qian's thatched hut is stocked with books; Emerson's journal entries attest to his capacious library. The Chinese bard discloses that he is often so engrossed in his reading that "he jovially forgets his meals" ("Life," Sun 72). He registers in "On Reading the Classic of the Hills and Seas” 《读山海经》 that browsing is his reward after farm work:

Ploughing is done and also I have sown
The time has come to return and read my books
I read at length the story of King Mu
And let my gaze wander over pictures of hills and seas
Thus with a glance I reach the ends of the Universe
If this is not a pleasure where could I ever find one

孟夏草木长，绕屋树扶疏。 既耕亦已种, 时还读我书。

Significantly, the rapture the poet derives from reading consists in being transported vicariously to "hills and seas"; the civilized pleasure unleashed by texts is of a piece with his delight in nature. 
Besides providing a blueprint for right living, nature as conceived by both Tao Qian and Emerson bespeaks a deeper ethic (whether grounded in Taoism or Transcendentalism) than social propriety or received morality. Tao Qian's “Peach Blossom Spring” situates the utopia in a secluded niche away from corrupt power holders, ruthless landlords, and greedy merchants; his poetry bears out a synergistic relay between the natural and ethical environment, between ecological boon and moral well-being. In “Six Songs of Poor Scholars"《咏贫 $士 》$, he associates a prosperous official life with "real pain”, and contrasts it with the poor scholar's rustic existence:

\author{
A bed of straw was always warm enough \\ And fresh-gathered yams were good enough for breakfast... \\ Poverty and wealth will always war within us \\ But when the Tao prevails there are no anxious faces \\ Utmost moral power will crown the village entrance \\ And purest chastity shine in the western gateway
}

\author{
刍槁有常温， \\ 采莒足朝飡…… \\ 贫富常交战， \\ 道胜无戚颜。 \\ 至德冠邦问， \\ 清节映西关。(Acker 132; Xu 118)
}

The poem, particularly the last two lines, exhibits a noted Taoist paradox: "Flex to remain whole;/Bend to be straight;/Empty to be filled;/Be worn and be renewed;/Seek less and gain;/Seek more and be dazed.../The self-effacing shines;/The humble wins acclaim;/Brag not and be decorated [曲则全 枉则直 洼则盈 粉则新, 少则得，多则惑。是以圣人抱一为天下式。不自见，故明 ; 不自是 , 故彰 , 不自伐 , 故有功]” (Gu 58; the author's translation). Tao Qian intimates that "utmost moral power" resides in the lowliest abode and "purest chastity" issues from the humblest quarter. Tucked away in remote mountains and hidden hamlets, his locus amoenus is free not only of air pollution but—perhaps more importantly—of political infighting and economic competition. The poet does not, however, downplay the hardship of being indigent. Laments about bitter cold and gnawing hunger crop up in another canto of "Six Songs of Poor Scholars", but the speaker consoles himself by observing that many ancient sages were in an analogous plight (“何以慰吾怀，赖古多此贤!”) (Acker 127).

Emerson, too, disparages worldly possession and dominion and couples salubrious milieu with ethical conduct: "The farmer imagines power and place are fine things. But the President has paid dear for his White House. It has commonly cost him all his peace, and the best of his manly attributes” (“Compensation,” 169). His reasoning, which implies that architectural grandeur and political clout are inversely proportional to inner peace and personal integrity, may have been inspired by Christ's Sermon on the Mount:

Blessed are the poor in spirit: for theirs is the kingdom of heaven.../Blessed are the meek: for they shall inherit the earth./Blessed are they which do hunger and thirst after righteousness: for they shall be filled. (Mathew 5:2-5)

The blessing for the spiritually hungry echoes the Taoist paradox cited above: "Empty to be filled." However, unlike the Beatitudes, which promise delayed gratification in the kingdom of heaven, the Book of Tao conveys the benefit of material abstinence here and now —an idea to which both Tao Qian and Emerson subscribe. Tao Qian shuns worldly profit and official life for the sake of self-cultivation; Emerson considers "the reliance on Property, including the reliance on governments which protect it, [as] the want of self-reliance" (163).

Like Tao Qian, Emerson exalts nature as a “discipline” that disseminates intellectual and moral truths:

Sensible objects conform to the premonitions of Reason and reflect the conscience. All things are moral; and in their boundless changes have an unceasing reference to spiritual nature... every natural process is a version of a moral sentence. 
The moral law lies at the centre of nature and radiates to the circumference.

As such, everything about a natural landscape educates:

What is a farm but a mute gospel?... Nor can it be doubted that this moral sentiment, which thus scents the air, grows in the grain, and impregnates the waters of the world, is caught by man and sinks into his soul. The moral influence of nature upon every individual is that amount of truth which it illustrates to him.... Who can guess how much firmness the sea-beaten rock has taught the fisherman? How much tranquility has been reflected to man from the azure sky, over whose unspotted deeps the winds forevermore drive flocks of stormy clouds, and leave no wrinkle or stain? (Nature, 28, 29)

Nature dispenses moral truth; the laws of nature translate into moral laws. A fisherman can learn from the sea-beaten rock to stand firm against adversity, and presumably also against the tide of public opinion; a man can learn from the azure sky to remain unruffled and unclouded by earthly storms and stresses.

By far the greatest lesson instilled by Nature is self-reliance. Using imagery that echoes the Taoist paradox "Bend to be straight", Emerson posits:

Nature suffers nothing to remain in her kingdoms which cannot help itself. The genesis and maturation of a planet, its poise and orbit, the bended tree recovering itself from the strong wind, the vital resources of every animal and vegetable, are demonstrations of the self-sufficing and therefore self-relying soul. (“Self-Reliance,” 153)

He adamantly holds that "what I must do is all that concerns me, not what the people think" (143). No less importunately than Tao Qian, he cautions against social pressure that induces one to kowtow to power, fame, or fortune: "Society is a joint-stock company... in which the members agree, for the better security of his bread to each shareholder, to surrender the liberty and culture of the eater. The virtue in most requests is conformity. Self-reliance is its aversion". Hence the oft-quoted corollary: "Whoso would be a man must be a nonconformist.... Nothing is at last sacred but the integrity of your own mind. Absolve you to yourself, and you shall have the suffrage of the world” (141). Emerson, ever against herd values, would applaud Tao Qian's decision to tune out "vulgar tone" so as to recover his inherent personality through self-sufficient husbandry.

Analogies abound between Emerson's transcendentalist notions of self-reliance and Tao Qian's reclusive ideas concerning self-sufficiency, as well as between their stances against societal affiliations. The Chinese poet reckons as obstacles to the Way of Tao what the New England sage remonstrates against as impediments to self-trust—dogma, property, government, discontent stemming from regret about the past, and anxiety about the future. Both espouse the paradox of "less is more", pitching natural living against material comfort, craven security, and obsequious existence.

\section{Divergent Ideas About Nature, Selfhood, and Solitude}

With regard to the definition and interconnection of nature, selfhood, and solitude, one discerns both striking coincidences and sharp discrepancies between Tao Qian and Emerson. Like-minded in their coordination of nature and solitude, the two regard studying nature and knowing oneself to be twin pursuits. But Tao Qian's ideas about nature and self veer from Emerson's. Tao Qian sees nature as a haven from feudal ministry; individuals must remove themselves to the countryside to cultivate their native temperament under the auspices of nature. For Emerson, it is the human mind that must intuit the meaning of the external world - which is not confined to rustic regions - and communicate its lessons. Hence nature can only manifest itself through agency. He anticipates Darwin's theory of evolution in designating homo sapiens as the highest form to which nature aspires while proclaiming, against both Darwinian atheism and orthodox Unitarianism, 
that "God is here within" ("Self-Reliance," 153). Where Tao Qian envisions the self to be living in concord with nature, Emerson bids the self-reliant individual to explicate the world, generating order out of chaos. The solitude that Tao Qian savors can be found only in the countryside; the kind that Emerson extols can be found anywhere by the self-possessed.

Tao Qian associates nature and solitude with the countryside, but not with a hermetic existence. While distancing himself from hubs of power and commerce, he continues to enjoy being with his family and friends. He reveals in “Retracing My Way Home: A Prose Poem [归去来辞]” that despite ending his “intercourse with the world [请息交以绝游]”, he is “pleased with the feeling words of... kin and friends [悦亲戚之情话]” (Sun $62,65)$. He describes the hard work of a farmer providing for his kin: "I have never yet utterly failed my family/Even though cold and hungry/they always had bran and gruel [身亲未曾替，寒馁常糟糠。]” “'Seven Miscellaneous Poems," Acker 78; Xu 111). He celebrates the joys of being surrounded by children: "Now I hold hands with a train of nieces and nephews,/Parting the hazel growth we tread the untilled wastes [试携子侄 辈，披榛步荒墟]” (“Five Poems,” 56; Xu 28). Above all, he revels in drinking with others: “Fond of wine, he is too poor to resort to it often; knowing this, his kin and friends would invite him to bumpers [性嗜酒 , 家贫不 能常得。亲旧知其如此，或置酒而招之]” (“Life,” Sun 72-73). The poet is a “hermit” only in the Chinese sense of choosing to live in a rural area, but still within human earshot. All he needs for his inner peace is the freedom to follow his heart’s desire, as celebrated in “Retracing My Way Home”《归去来辞》:

To be wealthy and to be high in rank are not what I wish; to be in the celestial city is not what I expect. I may wish to go somewhere on a fair day alone, or to weed and manure the soil... Or I may wish to rise on the eastern bank to halloo in easing my heart, or to compose poetry by the side of a limpid stream. In such wise, I may merge into Nature and come to my end, delighting in the decree of heaven and doubting nought. [富贵非吾愿, 帝乡不可期。怀良辰以孤往, 或植杖而 耘耔。登东鼻以舒啸，临清流而赋诗。聊乘化以归尽，乐夫天命复奚疑！] (Sun 62-63, 66-67)

It is worth noting here that although Tao Qian stresses his autonomy, the poet sees himself-whether fertilizing the soil, composing by a stream, or dissolving back into the earth eventually—as very much a part of the landscape. This point will be taken up again later in this paper's discussion of the Taoist sense of "self" as a vanishing act.

Tao Qian and Emerson share a free spirit and wish above all to be true to themselves and their inward promptings. The Chinese poet, as recounted earlier, does not deign to "grovel" for a living. Emerson, who values honesty and liberty far above tact, likewise refuses to ingratiate himself:

If you are noble, I will love you; if you are not, I will not hurt you and myself by hypocritical attentions... But so may you give these friends pain. Yes, but I cannot sell my liberty and my power, to save their sensibility.

Neither of them is willing to pay lip service to those they dislike. Just as Tao Qian would rise spontaneously on the eastern bank and halloo to ease his heart, so Emerson intends to do "whatever inly rejoices [him] and the heart appoints" (“Self-Reliance,” 155).

Nature for both men is the repository of knowledge and self-knowledge. Emerson asserts:

The first in time and the first in importance of the influences upon the mind is that of nature. Every day, the sun; and after sunset, Night and her stars. Ever the winds blow; ever the grass grows... The scholar is he of all men whom this spectacle most engages. (“The American Scholar," 53)

He believes that nature and the human soul are rooted in the same order, that a law of nature is also a 
human law, so much so that "the ancient precept, 'Know thyself,' and the modern precept, 'Study nature,' become at last one maxim” (54). But it is not always easy to nail down this lay philosopher's ideas owing to his contempt for consistency. While Emerson identifies the open air as the ideal setting for learning and for solitary communion in his first book Nature (1836), he opines in a later essay with the same title that nature is ubiquitous—as omnipresent as Tao:

If we consider how much we are nature's, we need not be superstitious about towns, as if that terrific or benefic force did not find us there also, and fashion cities. Nature who made the mason, made the house. We may easily hear too much of rural influences. The cool disengaged air of natural objects, makes them enviable to us chafed and irritable creatures with red faces, and we think we shall be as grand as they, if we camp out and eat roots; but let us be men instead of woodchucks, and the oak and the elm shall gladly serve us, though we sit in chairs of ivory on carpets of silk. ("Nature" [1844], 111)

In this piece nature and solitude are no longer confined to bucolic locales but within reach everywhere, even in an ornate boudoir, inasmuch as ivory and silk are also natural products. Nature even cycles as "thought" in this essay: "Nature is the incarnation of a thought, and turns to a thought again, as ice becomes water and gas". Hence "every moment instructs, and every object: for wisdom is infused into every form" ("Nature" [1844], 117). Nature here encompasses just about everything under the sun. The alert mind can be illuminated by any external objects, including those found indoors or in cities.

If nature is construed much more broadly in Emerson's later work, it is also much more contingent upon the apprehension of an individual who can actively shape the world around it, rather than passively receiving information from it. Solitude is also increasingly allied with self-reliance, more and more a prerogative of the inner self:

It is easy in the world to live after the world's opinion; it is easy in solitude to live after our own; but the great man is he who in the midst of the crowd keeps with perfect sweetness the independence of solitude. ("Self-Reliance," 143)

Solitude is nearly synonymous with independence here. This solipsistic mindset, linked to a firm individual conviction unshaken by popular opinions, must remain intact even when one is surrounded by a rabble.

Emerson thus goes much farther than Tao Qian in his insistence on self-amplifying solitude. Unlike the Chinese poet, who never shuns family and friends, Emerson declares that the mental state essential for self-reliance must preclude any extrinsic interference, including that of one’s closest kin:

Your isolation must not be mechanical, but spiritual, that is, must be elevation. At times the whole world seems to be in conspiracy to importune you with emphatic trifles. Friend, client, child... all knock at once at thy closet door... But keep thy state; come not into their confusion.... Say to them, "O father, O mother, O wife, O brother, O friend, I have lived with you after appearances hitherto. Henceforward I am the truth’s. Be it known unto you that henceforward I obey no law less than the eternal law... I must be myself. ("Self-Reliance,” 154-55)

Unlike Tao Qian, who remains mindful of his domestic duties, Emerson would turn a deaf ear to all immanent demands when the transcendentalist spirit beckons. The enjoinment to "keep thy state" appears to pun on "state" of mind and a sovereign "state": An individual must hold his own mind supreme like that that of a sovereign who does not have to heed anyone else. The next injunction (bidding parents, spouse, sibling, and friend to leave the speaker alone), which echoes 12-year-old Jesus's response to his mother, further elevates the sovereign into the role of the Son of God. The biblical teen, unbeknownst to his parents, has stayed behind in 
the temple in Jerusalem. Upon being rebuked, he ripostes: "How is it that ye sought me? wist ye not that I must be about my Father's business?” (Luke 2:49). Just as Christ's retort implies that his unique alliance with God supersedes earthly filiation, so individuals, Emerson argues, must get their priorities straight by ministering first to the God within.

Tao Qian and Emerson further differ in their ideas concerning the relationship between self and nature. Tao Qian, as his line about merging eventually into nature adumbrates, adheres to the Taoist worldview in which "man is not separated from nature either by intellectual discrimination or by emotional response; he is one with nature, and lives with it in harmony" (Levenson \& Schurmann 112). As in traditional Chinese paintings where human figures are often tiny specks amid grand landscapes, so the speaker in Tao Qian's "Retracing My Way Home”, as noted earlier, quietly blends in with nature, a fleeting presence in the scheme of things.

In contrast with Tao Qian, who is content to lead a self-effacing georgic existence, Emerson sees nature as "thoroughly mediate", subject to human orchestration:

It is made to serve. It receives the dominion of man as meekly as the ass on which the Saviour rode. It offers all its kingdoms to man as the raw material which he may mould into what is useful... One after another his victorious thought comes up with and reduces all things, until the world becomes at last only a realized will, — the double of the man. (Nature, 28)

Although Emerson is not espousing this as the only true relation between human and nature, the idea of nature serving humankind, who can also mold it into what is useful, goes against the Taoist grain of being subsidiary to nature. The last line, with its cocksure sense of nature as the realized human will, would never be uttered by Tao Qian or any traditional Chinese poet, not even grandiloquent Li Po or Su Shi. Emerson deems an enlightened person to be "the creator in the finite" (Nature, 43), with ascendency over nature, which presumably remains nebulous and inchoate till it is quickened by God-given human intelligence. While individuals can learn from nature, they must first invest the universe with meanings: "We animate what we can, and we see only what we animate. Nature and books belong to the eyes that see them” ("Experience,” 269).

Writing centuries after Tao Qian, Emerson has also incorporated scientific knowledge in his understanding of the world, as the epigraph for the 1849 edition of Nature shows:

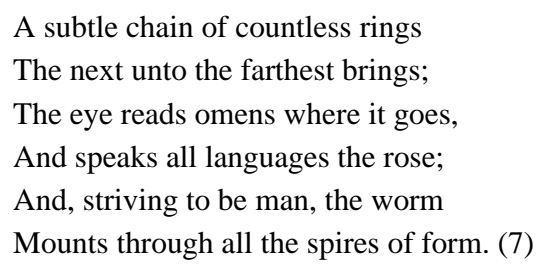

The chain at first glance resembles the Chain of Being in Renaissance British literature. But upon close examination, it looks not so much backward to the Elizabethan world picture as forward to Darwin's evolutionary theory. Instead of depicting humankind clambering up the ladder to the galaxy, "man" in this Emersonian hierarchy is the highest order of beings toward which the worm inches upward. Furthermore, while natural objects such as rose and worm embody fundamental lessons, it is the human eye that divines these omens. Nature itself cannot deliver any message until it is thus penetrated.

Because Emerson believes human beings to be endowed with godlike intelligence, cultivation of the self takes on very different forms than those found in Confucian or Taoist literature, in which the self must exist in 
harmony with the social or natural scheme of things. In Confucian culture, self-cultivation is often associated with self-control, self-restraint, even self-abnegation, and with learning one's place in multiple hierarchies. Although Taoism gives freer reign to the individual spirit, a human being, as one miniscule cog in the universal wheel, must not strive for a detached existence. In the words of Joseph Levenson and Franz Schurmann:

Nature is not merely observed, for observation implies separation of ego and object-a separation which, for the Taoists, isolates the self, thus condemning it to the striving they hold vain and to the suffering they see as the inevitable concomitant. It is identification with nature that banishes consciousness, a consciousness that in the last analysis is always and ominously of self. (112)

This Taoist diffusion, if not dissolution, of self, which has found its way into much of Tao Qian's poetry, is anathema to Emerson.

The Taoist and Transcendentalist construals of self and of the relation between self and nature are in some way encapsulated by Tao Qian and Emerson. William Acker's translation of one of Tao Qian's poems evinces this dissonance between a discrete self and one that is Taoistically absorbed:

$\begin{array}{ll}\text { Renouncing my cap of office I will return to my old home } & \text { 投冠旋旧墟 } \\ \text { Never more entangled with love for high position } & \text { 不为好爵索 } \\ \text { I will nourish my REAL self under my gates and thatch } & \text { 养真衡茅下 } \\ \text { And by doing this be all the better known } & \text { 庶以善自名 }\end{array}$

("Written in the Seventh Month of the Year Hsin-chou while Passing T'u-k'ou in the Night on my Way back to Chiang-ling for my vacation” [辛丑岁七月赴假还江陵夜行途口], Acker 111; Davis 70-71; Acker’s emphasis)

The line rendered as "I will nourish my REAL self" is at variance with the Chinese expression “养 真”—nurture natural disposition and cultivate truth—betraying the translator's Western bias for an inalienable self. In the Chinese idiom, nurturing disposition and cultivating truth are cognate pursuits, and the idea of an irreducible ego is notably absent. Tao Qian implies that it is through identifying with nature—and definitely not through raising self-awareness- that one can attain enlightenment. A related mistranslation occurs in the phrase "be all the better known". What the poet desires is not worldly prestige but a sense of honor. Tao Qian may be recasting a saying in Analects 《论语》: "Be not grieved that you are not known, but seek to be worthy of being known [不患无位, 患所以立; 不患莫己知, 求为可知也]” (Analects IV: 14; Collie 14). He makes this distinction himself when he writes: "After our death... our name should also perish.... Should we not labour... To do good in such a way that men will love us for it [身没名亦尽……立善有遗爱，胡为不自竭?]” (“Substance, Shadow, and Spirit,” Acker 46-47; Xu 18). Elsewhere, Tao Qian has also lamented that “The Tao has been lost... And people everywhere are misers of their feelings... And think of nothing save keeping their reputation [道丧向千载，人人惜其情。有酒不肯饮，但顾世间名]” ““Six Poems Written While Drunk,” Acker 65; Xu 65). He is unlikely to be vain along the same vein. A. R. Davis’s translation of these lines_- "I’ll cultivate truth 'under a cross-beam door';/So may I make myself a name for goodness” (I: 83) seems closer to the original meaning. ${ }^{5}$

Solitude for Tao Qian involves reclusiveness and asceticism; it is affiliated with intellectual independence in Emerson, in whom self-cultivation amounts to developing complete trust in one's intuition, to the degree of

\footnotetext{
${ }^{5}$ Davis's wording also provides an uncanny parallel to Emerson's oft-quoted (and Confucian-sounding) exaltation: "He who would gather immortal palms must not be hindered by the name of goodness, but must explore if it be goodness" ("Self-Reliance," 141). Both Tao Qian and Emerson yearn for an authentic core of being rather than a hollow reputation.
} 
making light of the teachings of past saints and savants and being deaf to the criticism of one's peers. Instead of seeing humans as dissolvable specks in the universe, he contends that "a true man... is the center of things. Where he is, there is nature" ("Self-Reliance," 147), while noting "the poverty of nature and fortune beside our native riches” (154). Because nothing is grander than the self-reliant mind, which holds its own compass, solitude for Emerson does not entail actual mountain retreat: "Think alone, and all places are friendly and sacred. The poets who have lived in cities have been hermits still. Inspiration makes solitude anywhere" (“Literary Ethics,” 105).

The restive independence Emerson champions differs from Tao Qian’s pragmatic self-sufficiency. Urging individuals to harken to their own callings without dreading public censure or hankering after popular acclaim, he famously exhorts: "Hitch your wagon to the star". He uses this sidereal axiom twice (once with a different possessive) in Society and Solitude: "Now that is the wisdom of a man, in every instance of his labor, to hitch his wagon to a star, and see his chore done by the gods themselves." And again: "Hitch your wagon to a star. Let us not fag in paltry works which serve our pot and bag alone.... Work rather for those interests which the divinities honor and promote" (Society and Solitude, 25, 27). Deployed in the first instance to describe human ingenuity in harnessing the forces of the elements and in the second to inspire humankind to harbor high principles, in common usage the phrase is often used as an exhortation to pursue lofty enterprises and to have faith in one's unlimited potential.

Although both Tao Qian and Emerson view knowing oneself and knowing nature as inextricably intertwined, the grand entelechy signaled by Emerson's starry metaphor differs from Tao Qian's low-key (if epicurean) pursuit. In lieu of the boundless confidence of the American lecturer, who proclaims, "Speak your latent conviction, and it shall be the universal sense" and "Trust thyself: every heart vibrates to that iron string" (“Self-Reliance,” 138, 139), Tao Qian describes himself as “spare of speech [闲静少言]”, writing merely “to please himself and show his bent [著文章自娱，颇示己志]”(“Life,” Sun 73).

\section{Relationship Between Self and Society}

The starkest difference between the two pastoral enthusiasts is their relationship to the world of affairs. Tao Qian, after his stints as civil servant, abstained completely from bureaucracy and ensconced himself in a rural backwater. He even changed his name from Tao Yuanming to Tao Qian-Qian meaning "hiding” or "submerging"- signifying his resolve to escape from the public eye and to avoid the tarnishing effects of official life.

Christy surmises that Emerson was nudged by his friends to do the same (possibly to go somewhere akin to the Peach Blossoms Spring): "[Amos Bronson] Alcott might have begged him to enter the ill-fated Fruitlands venture. Thoreau was considering Walden” (126). Fruitlands and Brook Farm were two of the most well-known Utopian communities of the mid-1840s. Emerson might be reluctant to join because of his distaste for group venture, for these were ultimately voluntary enterprises that imagined the reform of the world to be possible in advance of the reforms of individuals. But Christy, who infers Confucian leanings in Emerson from the journal of 1843, suspects he stayed put out of a Confucian sense of duty, aligning himself with the Chinese sage, “with Alcott and Thoreau as Chang Tsoo [长沮] and KeeNeih [桀溺]”:

Chang Tsoo and KeeNeih retired from the state to the fields on account of misrule, and showed their displeasure at Confucius who remained in the world. Confucius sighed and said, "I cannot associate with birds and beasts. If I follow not man, whom shall I follow?” [长沮、桀溺耦而耕。使子路问津焉… 夫子怃然曰 : “乌兽不可与同群 , 吾非斯人之徒 
与而谁与！天下有道，丘不与易也。] (Journals VI: 403; quoted in Christy 126)

Notwithstanding his insistence on resolute intellectual freedom and his reproof of a controlling political organ ("the State must follow, and not lead the character and progress of the citizen"), Emerson remains scrupulously mindful of his "Confucian" duty to the state by continuing to be a public spokesman after resigning as Unitarian minister.

In his opinion, a true thinker must not retreat from an imperfect world but must assay to usher in a brave new world:

Let us affront and reprimand the smooth mediocrity and squalid contentment of the times, and hurl in the face of custom, and trade, and office, the fact which is the upshot of all history, that there is a great responsible Thinker and Actor working wherever a man works.... Every true man is a cause, a country, and an age.... A man Caesar is born, and for ages after we have a Roman Empire. Christ is born, and millions of minds so grow and cleave to his genius.... An institution is the lengthened shadow of one man... and all history resolves itself very easily into the biography of a few stout and earnest persons. ("Self-Reliance," 147-148)

Instead of retiring from society, Emerson implores the reader to "affront and reprimand", to remove obstacles to progress, to affirm that outstanding individuals such as Caesar and Christ could advance civilizations, that every human has the potential to become a vanguard. Drawing a sharp distinction between geniuses and social institutions, he's all for the one, and none for the other. Instead of succumbing to institutional constraints, a genuine leader can overhaul the institution.

The obligations of a seminal mind through everyday action are expounded in "The American Scholar":

There goes in the world a notion that the scholar should be a recluse, a valetudinarian, — as unfit for any handiwork or public labor as a penknife for an axe.... Action is with the scholar subordinate, but it is essential. Without it he is not yet man. Without it thought can never ripen into truth... Inaction is cowardice, but there can be no scholar without the heroic mind. The preamble of thought, the transition through which it passes from the unconscious to the conscious, is action. Only so much do I know, as I have lived. Instantly we know whose words are loaded with life, and whose not. ("The American Scholar," 59)

Thinking and active living, according to Emerson, must go hand in hand. The office of this scholar of action "is to cheer, to raise, and to guide men by showing them facts amidst appearances" (62). He must figure things out for himself and forego the "pleasure of treading the old road, accepting the fashions, the education, and the religion of society", he must bear the cross of being contrary, endure poverty and solitude, and "the state of virtual hostility in which he seems to stand to society, and especially to educated society" (63). He can only take as consolation the awareness that he is the repository of wisdom for others, exercising the highest human functions: "He is the world's eye. He is the world's heart" (63). The American scholar, in short, must act as the social conscience and communicate the noblest thoughts and sentiments to the public.

Emerson himself never retracts from his self-appointed mission as the world's eye and heart, as the seer and conscience of his age; he continues to bring his considerable talents to bear on flashpoint events of his time. Much as he craves solitude, he maintains that "the reason why an ingenious soul shuns society, is to the end of finding society. It repudiates the false, out of love of the true" ("Literary Ethics," 105). Much as he "begrudged acting as a public man”, he spoke out against three major political issues during his prime: the expulsion of the Cherokees from Georgia, the war against Mexico, and slavery (Bode xvi; see also Petrulionis, 2006; Menand, 2002). The entry on Emerson in The Imperial Dictionary of Universal Biography provides a cogent assessment: 
It is no slight sign of the greatness of the thinker, that he can leave the amenities of the city and the quietudes of the forest to stand upon the anti-slavery platform. The subordination of the pursuit of a thought to the love of a duty thus manifested, may be accepted as the crowning lesson in the life and works of Emerson. (Part 4: 245)

\section{Nature, Spirit, and Writing}

Having discussed the points of convergence and divergence in these two men of letters, this paper now turns to their metaphysics and aesthetics, which are alike informed by their regard for nature. Despite a spiritual strain that often accompanies their compositions, and the respective Taoist and biblical allusions therein, neither of them devotes much thought, if at all, to life after death. Their works, presented in limpid and unadorned verse and prose free of abstruse references, seem natural growths from the soil of old China and New England. Instead of citing precedents and bowing to hoary authority, they appeal to firsthand experience and intuition. In both, one finds a tonic blend of piety and irreverence.

The Chinese poet openly embraces the beliefs of Tao as moral and eternal, but he steers clear of ZhuanZi's mysticism and occult folk practices associated with Taoism (such as the search for elixirs via alchemy). Take, for example, “Substance, Shadow, and Spirit”《形影神》:

Appearing by chance/[man] comes into this world,/And suddenly is gone never to return.... I have no art/to soar and be transfigured.... I cannot tell you how to preserve life,/And have always been inept/in the art of guarding it. [适见在世 中，奄去靡归期。我无腾化术，必尔不复疑] (Acker 45-45; Xu 16-18)

Tao Qian clearly does not place much credence in an afterlife: "To be in the celestial city is not what I expect [帝乡不可其]” (“Retracing My Way Home,” Sun 66-67). He is content to bookend life with birth and death: "To be born in the morning possessed of Love and Faith/And die at evening, what more could one desire [朝与仁义生 ,夕死复何求?]” “"Six Songs of Poor Scholars,” Acker 130). The elegy below is a variation on the same theme of human finitude:

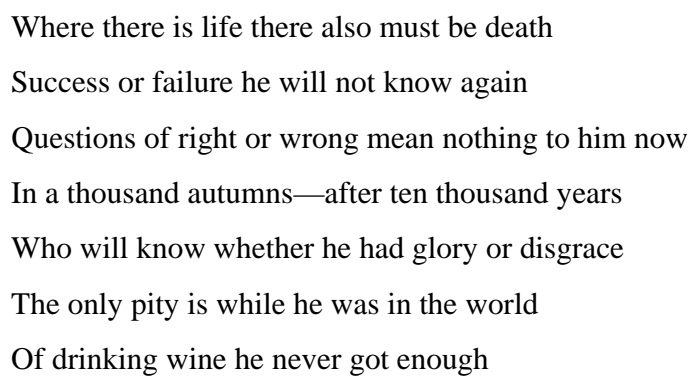

(“Three Songs Written in Imitation of Ancient Bearers’ Songs” [挽歌诗三首（其一）], Acker 101-102; Xu 132)

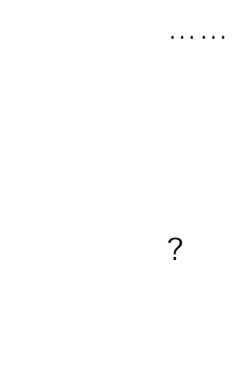

The sentiment is replicated in “Written on the Ninth Day of the Ninth Month of the Year I-yu”《已西岁九 月九日》:

From ancient times/there was none but had to die,/Remembering this scorches my very heart./What is there I can do to assuage this mood?/Only enjoy myself drinking my unstrained wine./I do not know about a thousand years,/Rather let me make this morning last forever. [从古皆有没，念之中心焦。何以称我情? 浊酒且自陶。千载非所知, 聊以永今朝]” (“Written on the Ninth Month of the Year I-yu,” Acker 121-22; Xu 58).

Though the thought of eventual nothingness sometimes gives rise to melancholy, the poet uses this unpleasant fact to counsel against transient glory and prompt his readers to make the most of their numbered days. 
His recurrent advice is to drink before it is too late. The poet definitely practices what he preaches, as borne out by one of his several poems entitled “Drinking”《饮酒》:

\begin{tabular}{|c|c|}
\hline I set up my cottage in the world of men & 结庐在人境, \\
\hline Away from the hubbub of horses and carriages & 而无车马喧。 \\
\hline Being asked how it could be thus, I reply & 问君何能尔, \\
\hline My heart stays apart, so secluded must be the spot & 心远地自偏。 \\
\hline In plucking chrysanthemums beneath the east hedge & 采菊东篱下, \\
\hline I vacantly see the southern mountains afar & 悠然见南山; \\
\hline The mountain aura hovereth fair morn and eve & 山气日夕佳, \\
\hline The birds fly from and back to their nests early and late & 飞鸟相与还。 \\
\hline There is the pith of truth in all this sight & 有真意; \\
\hline When I am about to say how, I forget my words & 欲辨已忘言。 \\
\hline
\end{tabular}

The poem is deceptively simple. While the first two quatrains use concrete imagery and everyday language to answer a simple question and evoke a rustic scene, the last two lines bring the self-analysis to a philosophical (but not at all didactic) close. The enigmatic couplet invites at least two interpretations. In light of the title, the poet may be too inebriated to find words to flesh out his insights. Or the insights may be too deep for articulation, like those referenced in "The Book of Tao": "The Tao that can be expressed in words/Is not the true and eternal Tao [道可道，非常道]” (Gu 3). The “pith of truth” gleaned by the Chinese poet from his nature-watch perchance surpasses language; his epiphany—possibly precipitated by alcohol—must be intuited rather than verbalized.

“Drinking” is emblematic of Tao Qian’s disarming and resonant style, which modulates lithely from a descriptive to a philosophical register. He has indicated in "Life" that he does not chase after fancy diction or obscure references, that he "takes delight in books, but is not enmeshed in mere words [好读书，不求甚解]" (Sun 72-73). On account of his verbal transparency the bard was "slighted by his era's critics and only fully appreciated by later generations of readers" (Stuewe 2071). Unlike his contemporaries, who flaunt their learning by observing rigid conventions, citing literary authorities, and using esoteric references, Tao Qian writes directly, using down-to-earth expressions and vignettes from country life. In the words of David Hinton, "Tao was the first writer to make poetry of his natural voice and immediate experience, thereby creating the personal lyricism which all major Chinese poets inherited and made their own” (5). He was keenly admired by Tang poets such as Meng Haoyan 孟浩然 and Wang Wei 王维 on account of “the freshness of his images, his homespun but Heaven-aspiring morality, and his steadfast love of rural life” (Stuewe 2073).

The overlapping contours of rustic vista and moral high ground in Tao Qian anticipates Emerson's claim that "particular natural facts are symbols of particular spiritual facts” (Nature, 19). Indeed, Emerson's ideas about the "Over-soul” or "the eternal One” are almost indistinguishable from Lao Zi’s and Tao Qian's delineations of the eternal Tao. Although the one-time pastor refers frequently to God in his work, his idea of divinity is much closer to the Taoist universal spirit than to the Judeo-Christian God:

Spirit... suggests the absolute. It is a perpetual effect. Of that ineffable essence which we call Spirit, he that thinks most, will say least. We can foresee God in the coarse... but when we try to define and describe himself, both language and thought desert us, and we are as helpless as fools and savages. That essence refuses to be recorded in propositions, when man has worshipped him intellectually, the noblest ministry of nature is to stand as the apparition of God. It is the 
organ through which the universal spirit speaks to the individual, and strives to lead back the individual to it. (Nature, 41)

Here and elsewhere Emerson's cogitations about the universal spirit sound exactly the same as the Taoist paradox about ineffable truth: "the highest truth on [Intuition] remains unsaid; probably cannot be said; for all that we say is the far-off remembering of the intuition" ("Self-Reliance," 152); "My words do not carry its august sense; they fall short and cold” (“The Over-Soul,” 211). The transcendentalist’s assumptions coincide with Lao Zi's philosophy regarding the interconnection of everything; accessibility of the Spirit to all; alignment of the divine and the human (through self-cultivation); manifestation of the comic or transcendentalist ethos in immanent action.

Like Tao Qian, Emerson is loath to dwell on the afterlife:

Men ask concerning the immortality of the soul, the employments of heaven... and so forth... These questions which we lust to ask about the future... God has no answer for them [!]... It is not in an arbitrary "decree of God," but in the nature of man, that a veil shuts down on the facts of to-morrow... By this veil which curtains events it instructs the children of men to live in to-day. (“The Over-Soul,” 219-220; the author’s exclamation mark)

A Confucius saying readily comes to mind: “If we don’t know life, how can we know death? [末知生 , 焉 知死?]” (Analects, Xian Jin 先进: 11). Emerson, speaking putatively on behalf of God, likewise dismisses interests in posthumous affairs as "low curiosity" and urges his readers to channel their energy into the here and now: "work and live, work and live" (220).

Stylistically, Emerson also mirrors Tao Qian’s poetic immediacy, using figurative language spontaneously to imbue abstract ideas with welcome clarity. There are even uncanny echoes in “Self-Reliance” of Tao Qian's "Drinking”. The Chinese poet does not miss stately conveyances, preferring natural resources. The "pith of truth" for him is embedded in the profuse mountain air that is available throughout the day, in the birds that go out with sunrise and return at sunset. Emerson, too, prefers living in sync with nature to modern conveniences:

The civilized man has built a coach, but has lost the use of his feet. He is supported on crutches, but lacks so much support of muscle. He has a fine Geneva watch, but he fails of the skill to tell the hour by the sun... and it may be a question whether machinery does not encumber; whether we have not lost by refinement some energy, by a Christianity, entrenched in establishments and forms, some vigor of wild virtue. (“Self-Reliance,” 162)

Had Emerson been Tao Qian's coeval, probably he too would have chosen a secluded spot "away from the hubbub of horses and carriages”, learning to tell time, build muscles, cultivate wild virtue, and decipher truth from an invigorating vicinity.

Emerson envisions not only a moral symbiosis between humankind and nature, but also a homological relation between microcosm and macrocosm, between the inmost and the outmost, so that an unadulterated individual can readily cull moral lessons from the external world:

The visible creation is the terminus or the circumference of the invisible world. A life in harmony with Nature, the love of truth and virtue, will purge the eyes to understand her text. By degrees we may come to know the primitive sense of the permanent objects of nature, so that the world shall be to us an open book, and every form significant of its hidden life and final cause. (Nature, 25)

This passage can easily pass for a Taoist gloss, and nature rubs off as much on Emerson's style as it does on Tao Qian's. Convinced that "every appearance in nature corresponds to some state of the mind, and that state of the mind can only be described by presenting that natural appearance as its picture” (Nature, 20), Emerson is no less felicitous at drawing inspirations from the surrounding landscape. In addition to the tropes 
of the sun, rain, stars, blade of grass, blowing rose, and worm introduced earlier, he has forged piquant conceits in lines such as "the world globes itself in a drop of dew... God reappears with all his parts in every moss and cobweb” (“Compensation,” 171).

Like the Chinese poet, Emerson flouts the authority of the ancients and the foreign influence of his contemporaries, recommending instead an original relationship with the cosmos:

Why should not we have a poetry and philosophy of insight and not of tradition, and a religion by revelation to us, and not the history of [our predecessors]? Embosomed for a season in nature, whose floods of life stream around and through us, and invite us by the powers they supply... why should we grope among the dry bones of the past, or put the living generation into masquerade out of its faded wardrobe? The sun shines today also. There is more wool and flax in the fields. There are new lands, new men, new thoughts. Let us demand our own works and laws and worship. (Nature, 7)

This passage, in which Emerson bemoans how veneration for past theories has sapped the creativity of his generation, is also a rhetorical tour de force. He obeys his own precept by seldom citing other authorities to support his observations, confronting the reader instead with spectacular evidence from the teeming fields. After posing a series of probing questions, he directs the reader's eye to the plenitude of the New World with three crisp sentences before ending with a simple exhortation, rendered all the more persuasive by the preceding imagery yoking classical antiquity to the macabre and coupling personal intuition with cornucopia. Through such graphic imagery the American scholar drives home the point that books by one's forefathers are no match for nature in providing individuals with the raw material for philosophy and poetry. Each person must learn to "detect and watch that gleam of light which flashes across his mind from within, more than the luster of the firmament of bards and sages" ("Self-Reliance," 139). He mentions other worthies of the past only to further bear out his point: "the highest merit we ascribe to Moses, Plato and Milton is that they set at naught books and traditions, and spoke not what men, but what they thought” (138-139). These men are great precisely because they put little stock in their predecessors and contemporaries.

Emerson rivals Tao Qian in articulating his thoughts briskly and winsomely. "Self-Reliance” concludes thus:

A political victory, a rise of rents, the recovery of your sick, or the return of your absent friend... raises your spirit, and you think good days are preparing for you. Do not believe it. Nothing can bring you peace but yourself. Nothing can bring you peace but the triumph of principles. (164)

These sentences cut a fetching arc. Emerson starts by taking the reader (addressed intimately in the second person) for a seductive rhetorical spin, via a lengthy sentence full of promising scenarios, till she is stopped in her tracks by the summary enjoinder: "Do not believe it". He then ends with two anaphoric sentences, pounding his message home. The periodical structure, turn of thought, and teasing suspense are of Tao Qian's vintage, at once playful and soulful, proffering instruction and diversion in equal measure. The metaphysical observations and stylistic maneuvers of these two masters seem part and parcel of their resolute individuality and their enchantment with nature.

\section{Conclusion}

Tao Qian and Emerson speak to readers afresh in this materialist age riddled with social pressures and ecological concerns. Though separated by millennia and a vast ocean, the two transpacific pillars might be considered kindred spirits with singular affinities: propensity for rustic living and seclusion; disdain for 
establishment, gilded acquisition, and servile conformity; predilection for self-cultivation and recourse to nature for intellectual and moral guidance; adherence to a spirituality that pertains to the here and now; and preference for a plain style not laden with erudite allusions or external authorities. Because of their disparate notions of selfhood, however, the two envisage the relationship between self and nature and between self and society dissimilarly. Although both thinkers strive to be true to themselves, Tao Qian perceives the self as a relatively insignificant "shadow" subsumed by natural landscape ("Vast and majestic, mountains embrace your shadow"); Emerson, for his part, adverts to the salience of a unique human intelligence in radiating divine wisdom and illuminating a higher ethic. Tao Qian can find solitude only in the countryside; Emerson holds that where "a true man is... there is nature”. Instead of retreating from the public world, he continues to denounce benighted practices and unjust policies. Still, these two aficionados of solitude share a profound belief in the intercourse of mindscape and landscape. They see the visible world as a living text awaiting apprehension by a soul attuned to its lessons, whether during a moment of heightened (if occasionally tipsy) reverie or in a flash of intuition.

\section{References}

Acker, W. (Trans.). (1952). T'ao the hermit: Sixty poems by T'aoCh'ien (365-427). London: Thames and Hudson.

Author, A. A. (1857). Emerson. In The imperial dictionary of universal biography: A series of distinguished memoirs of distinguished men, of all ages and all nations (pp. 244-245). London: William Mackenzie.

Birch, C. (Ed.). (1965). Anthology of Chinese Literature: Vol. 1. From early times to the fourteenth century. New York: Grove Press.

Bode, C. (1979). Introduction. In The portable Emerson (pp. Ix-xxxii). New York: Penguin.

Bode, C., \& Cowley, M. (Eds.). (1979). The portable Emerson. New York: Penguin.

Cady, L. V. (1961). Thoreau's quotations from the Confucian books in Walden. American Literature, 33(1), 20-32.

Carpenter, F. I. (1930). Emerson and Asia. Cambridge: Harvard UP.

Chen, D. T. Y. (1972). Thoreau and Taoism. In C. D. Narasimhaiah (Ed.), Asian response to American literature (pp. 406-416). New York: Barnes and Noble.

Christy, A. (1932). The Orient in American Transcendentalism: A study of Emerson, Thoreau, and Alcott. New York: Columbia UP.

Collie, D. (Trans.). (1828). Analects, IV. 14. In The Chinese classical work commonly called the Four Books. Malacca: Mission P.

Davis, A. R. (Ed.). (1983). Tao Yüan-ming: His works and their meaning (Vol. 2). Cambridge: Cambridge University Press.

Dimock, W. C. (2006). Through other continents: American literature across deep time. Princeton: Princeton University Press.

Emerson, R. W. (1909). Journals of Ralph Waldo Emerson. R. W. Emerson \& W. E. Forbes (Eds.). Boston: Houghton Mifflin.

Emerson, R. W. (1983). Literary ethics. In Essays and lectures: Nature: Addresses and lectures/essays: First and second series/representative men/English traits/the conduct of life (pp. 95-112). New York: Library of America.

Emerson, R. W. (2006). Politics. In Ralph Waldo Emerson: Selected essays, lectures, and poems (pp. 253-266). New York: Random House.

Emerson, R. W. (2007). Nature. In Collected essays: Complete original second series (pp. 103-117). Rockville, Maryland: ARC Manor.

Emerson, R. W. (2008). Society and solitude: Twelve chapters. Ann Arbor: University of Michigan.

Gu, Z. K. (Trans. \& Ann.). (2013). The book of Tao and Teh. 北京: 中国出版集团.

Gu, Z. K. (2013). Lao Zi and his philosophical system: An introduction. In Z. K. GU (Trans. \& Ann.), The book of Tao and Teh (pp. 27-58). 北京: 中国出版集团.

Gura, P. F. (2008). American Transcendentalism: A history. New York: Hill \& Wang.

Hinton, D. (1993). Introduction. In The selected poems of T'aoCh'ien (D. Hinton, Trans.) (pp. 5-14). Port Townsend, WA: Copper Canyon Press.

Kerouac, J. (1961). Running through (Chinese Poem Song). Retrieved from http://archive.neopoet.com/node/1075

Levenson, J. R., \& Schurmann, F. (1971). China: An interpretive history: From the beginnings to the fall of Han. Berkeley: U of California P. 
Marx, L. (1986). Pastoralism in America. In S. Bercovitch \& M. Jehlen (Eds.), Ideology and classic American literature (pp. 36-69). New York: Cambridge UP.

Menand, L. (2002). The metaphysical club: A story of ideas in America. New York: Farrar, Straus and Giroux.

Obeidat, M. (1988). Ralph Waldo Emerson and the Muslim orient. The Muslim World, 78(2), 132-45.

Packer, B. L. (2007). The Transcendentalists. Athens, GA: University of Georgia Press.

Pauthier, G. (Trans.). (1875). Les Livres sacrés de L'Orient (Sacred books of the Orient). Retrieved from http://gallica.bnf.fr/ark:/12148/bpt6k5860150t

Petrulionis, S. H. (2006). To set this world right: The antislavery movement in Thoreau's concord. Ithaca: Cornell University Press.

Richardson, R. D. (1996). Emerson: The mind on fire. Berkeley: University of California Press.

Stuewe, P. (1988). T’aoCh'ien. In F. Magill (Ed.), Great lives from history: Ancient and medieval series: 5 (pp. 2070-2074). Pasadena, CA: Salem Press.

Sun, D. Y. (Ed. \& Trans.). (1995). 古诗文英译集 (An anthology of ancient Chinese poetry). Shanghai: Shanghai Foreign Language Education Press.

Xiao, T. (1982). 陶渊明传 (Tao Yuanming’s biography). In W. XU (Ed.), 陶渊明诗选 (Selected poetry of Tao Yuanming) (pp. 1-6). Hong Kong: Joint Publishing Co..

Xu, W. (Ed.). (1982). 陶浰明诗选 (Selected poetry of Tao Yuanming). Hong Kong: Joint Publishing Co.. 